\title{
An updated cohort mortality study of workers exposed to styrene in the reinforced plastics and composites industry
}

\author{
Otto Wong, Lisa S Trent, M Donald Whorton
}

\begin{abstract}
Mortality data have been updated for a further 12 years for a cohort of workers in the reinforced plastics and composites industry with exposures to styrene monomer and other chemicals. The cohort consisted of 15826 male and female employees who were exposed to styrene for at least six months between 1948 and 1977 at 30 participating manufacturing plants in the United States. A total of 1628 deaths were reported during the extended observation period, 1948-89. Mortality from several causes showed significant increases-namely, all causes, all cancers, oesophageal cancer, lung cancer, cancer of the cervix uteri, cancer of other female genital organs, hypertensive heart disease, certain non-malignant respiratory diseases, motor vehicle accidents, and homicides. When, however, mortality data were examined in terms of duration of employment, durations of styrene exposure, and cumulative styrene exposure no upward trend was detected in any of these causes of death. Most of the increases in mortality were among workers who were employed for only six months to a year or who had very low cumulative exposure (< 10 ppm-years). Therefore, the increased mortality was not likely to be related to exposure to styrene. Several explanations for the increased mortality are offered, including low socioeconomic class, smoking, and lifestyle factors characteristic of short term workers. There was no increased mortality from lymphatic and haematopoietic cancers overall or from any specific haematological malignancies. In particular, no increase in mortality from non-Hodgkin's lymphoma, Hodgkin's disease, multiple myeloma, or leukaemia was found. Furthermore, detailed exposure-response analyses did not show any relation between exposure to styrene and any of these haematological malignancies. The lack of an exposure-response relation further supports the conclusion that workers in the reinforced plastics industry in this study did not experience any increased risk of lymphatic and haematopoietic cancers as a result of their exposure to styrene.
\end{abstract}

(Occup Environ Med 1994;51:386-396)
Styrene is a commercially important chemical widely used in the manufacture of synthetic rubber, resins, polyesters, plastics, and insulators. The biomedical effects of styrene have been studied both experimentally and epidemiologically. There are extensive publications on the mutagenicity of styrene. In a recent comprehensive review, Preston has concluded that styrene is not mutagenic, but that more studies are needed to determine the role of styrene oxide as a mutagenic intermediary in the metabolism of styrene in vivo. ${ }^{1}$ Furthermore, results from existing cytogenetic studies are equivocal. ${ }^{23}$

The potential carcinogenic effects of styrene in humans have been assessed primarily through occupational epidemiological studies. Occupational exposure to styrene occurs in the styrene-butadiene rubber, styrene monomer and polymerisation, and reinforced plastics industries. In the first two industries, levels of styrene exposure are relatively low, generally less than $5 \mathrm{ppm}$, but the potential for exposure to many other chemicals may be high. By comparison, levels of styrene exposure in the reinforced plastics industry have been and remain relatively high, with time weighted averages (TWAs) up to $200 \mathrm{ppm}$ in some instances. Also, the potential for coexposures, such as to benzene or 1,3-butadiene, is much lower or non-existent in the reinforced plastics industry. Thus the reinforced plastics industry offers the most suitable human data to consider some of the health issues of styrene.

Wong ${ }^{4}$ previously reported the mortality of a cohort of nearly 16000 male and female workers in the United States reinforced plastics industry. The overall mortality was as expected. No significant increase in mortality from cancer of all sites or from any specific site was found. Because of the young cohort and the short follow up, however, the study did not have adequate statistical power to detect a modest increase in certain diseases such as leukaemia. ${ }^{4-6}$ Also, the proportion of cohort members with unknown vital status was high (16\%), further limiting interpretation of the study results. The study has now been updated, and this report summarises the conduct and results of the updated study.

Materials and methods

The original cohort consisted of 15908 male and female employees at 30 reinforced plastics plants. ${ }^{4}$ To be included in the cohort, an employee must have worked in areas with 
exposure to styrene for at least six months between 1 January 1948 and 31 December 1977. The study has now been updated from 1977 to 1989 . Sources of information on vital status in the update included the participating plants, the Social Security Administration's Death Master File, the National Death Index of the National Center for Health Statistics, and a commercial retail credit bureau. Based on information from these sources, death certificates were obtained from individual state health departments. Causes of death were coded according to the revision of the International Classification of Diseases (ICD) in effect at the time of death.

Person-years of observation started after six months of exposure to styrene, and ended on the date of death or 31 December 1989 (whichever was earlier). For those lost to follow up (unknown vital status), personyears were counted up to the last date of contact. Person-years were classified by age (five-year groups), sex, and calendar year (five-year groups). Expected deaths were based on United States national age-sexcause-race-year-specific death rates. Cause specific standardised mortality ratios (SMRs) were computed with the University of Pittsburgh OCMAP computer program. ${ }^{?}$ Because race information was missing from employment records for most of the cohort, for SMR calculations the entire cohort was assumed to be white.

The Cox proportional hazards model was also used in analysing some selected causes of death. ${ }^{89}$ One important advantage of the Cox model was that the actual exposure data (for example, duration of exposure in years and cumulative exposure in ppm-years), instead of grouped data, could be used. An additional advantage was that only internal cohort data were used, whereas SMR analyses were based on comparisons with external populations. The actual computation was performed with the SAS PHREG procedure. ${ }^{10}$ Independent variables included age, sex, duration of exposure, and cumulative exposure. Because of software limitations, both duration of exposure and cumulative exposure were treated as fixed variables in the proportional hazards model analysis. This had little practical impact on the results, as most deaths occurred after 1977 when work and exposure assignments were truncated (see later).

The 30 reinforced plastics plants in the study manufactured various products including sheet moulding compounds, bulk moulding compounds, tanks, pipes, ducts, boats, panels, auto-parts, trays, and small parts. The first year of styrene use ranged from 1948 to 1968. At the time of the original epidemiological study, a parallel exposure assessment study was conducted by $\mathrm{AD}$ Little Inc. ${ }^{11}$ Individual plants were visited by a field survey team and a detailed industrial hygiene assessment was conducted at each plant to measure current (around 1980) exposure levels of styrene and other substances. Information on work practices, past industrial hygiene measurements, process changes and modifica- tions, engineering controls, and personal protective equipment was also obtained.

A job exposure matrix was developed for each plant, assigning a current styrene eight hour TWA and an exposure range to each job. Based on information on changes with time, historical TWAs were likewise estimated. Job categories in which typical TWA estimates for styrene were low included finish and assembly (5 ppm), store and ship (5 ppm), office and others (2 ppm), inject moulding (4 ppm), field service ( $5 \mathrm{ppm})$, preform production (7 $\mathrm{ppm}$ ), and pultrusion (5 ppm). Job categories with moderate TWAs (20-45 ppm) included sheet moulding compound production, gel coating, and winding. A typical styrene exposure in the spray up/lay up job category was $60 \mathrm{ppm}$ TWA with a range of 5 to $120 \mathrm{ppm}$, reflecting considerable differences among facilities and nature of specific work activities. Overall, TWAs by job category ranged from 1 to $200 \mathrm{ppm}$.

In the current study, six process categories with similar exposures to styrene and other substances were created based on the $\mathrm{AD}$ Little survey ${ }^{11}$ and a consideration of both processes and job activities. The six categories are open mould processing, mixing and closed mould processing, finishing operations, plant supports, maintenance and preparation, and supervisory and professional.

A quantitative styrene exposure index was also developed. Based on the employment history of each cohort member and the exposure estimates derived from the job exposure matrix for that particular plant, an appropriate TWA was assigned to each job in a worker's employment history. A cumulative exposure in ppm-years, calculated as the sum of products of TWA and duration of exposure of each job, was developed for each cohort member.

For about 550 workers (3\% of the total cohort), specific departments and jobs were not available from their employment records. These workers had more than six months of employment after styrene use was introduced at their respective plants, and were presumably exposed. The exposure levels were unknown, however, and for the purpose of calculating cumulative exposures, $0 \mathrm{ppm}$ was assigned to these unknown jobs. For a few jobs, even though job titles were available from employment records, it was not possible to quantify the exposure levels. These jobs were non-specific in nature, and tended to have minimal exposure. In the cumulative exposure calculation, a value of $5 \mathrm{ppm}$ was assigned to these jobs. It was not feasible to update employment histories of cohort members for the current investigation. Therefore, all work assignments as well as exposure assignments were truncated at the end of 1977 , the closing date of the original study.

\section{Results}

During the update, an extensive review of the data identified 30 duplicate records in the original study, which were consolidated. 
Table 1 Descriptive statistics of the cohort

\begin{tabular}{lc}
\hline Description & No of workers (\%) \\
\hline Total cohort & 15826 \\
Male & $11958(75 \cdot 6)$ \\
Female & $3868(24 \cdot 4)$ \\
Duration of employment (y) at 31 December $1977:$ \\
$0 \cdot 5-0 \cdot 9$ & $3712(23 \cdot 5)$ \\
$1 \cdot 0-1 \cdot 9$ & $3528(22 \cdot 3)$ \\
$2 \cdot 0-4 \cdot 9$ & $4326(27 \cdot 3)$ \\
$\geqslant 5 \cdot 0$ & $4260(26 \cdot 9)$ \\
Cumulative exposure in ppm-years at 31 December $1977:$ \\
Less than 10.0 & $3778(23 \cdot 9)$ \\
$10 \cdot 0-29 \cdot 9$ & $4119(26 \cdot 0)$ \\
$30 \cdot 0-99 \cdot 9$ & $4210(26 \cdot 6)$ \\
$\geqslant 100 \cdot 0$ & $3719(23 \cdot 5)$ \\
Vital status at 31 December 1989: & \\
Alive & $13651(86 \cdot 2)$ \\
Dead & $1628(10 \cdot 3)$ \\
With death certificates & $1586(97 \cdot 4)$ \\
Without death certificates & $42(2 \cdot 6)$ \\
Unknown & $547(3 \cdot 5)$ \\
\hline
\end{tabular}

Work histories of the entire cohort were also thoroughly examined. A total of 52 workers had less than six months of styrene exposure, and were thus ineligible for the cohort. Included in the final analysis were 15826 workers with at least six months of exposure to styrene (table 1). The total number of person-years increased from 122078 in the original study to 307932 in the updated study. The percentage of workers with unknown vital status in the updated study (3.5\%) was much less than in the original $(16 \cdot 1 \%)$. The number of deaths identified was $1628(10 \cdot 3 \%)$. Death certificates were obtained for 1586 decedents $(97 \cdot 4 \%)$. The 42 decedents without death certificates were included in the overall SMRs but not in cause specific SMRs.

Table 2 presents the cause specific SMR analysis for the entire cohort. In general, results for both men and women were similar and, therefore, results are not presented separately by sex. Overall mortality was increased for the entire cohort. Although this increase was not large $(7 \cdot 9 \%)$ it was statistically significant at the 0.01 level. Also statistically significant was the increase for all cancers (SMR = $115 \cdot 5)$.

A $10 \%$ increase (NS) in cancer of the digestive organs was found for the entire cohort. There were 14 deaths ascribed to oesophageal cancer, significantly higher than the 7.30 expected $(S M R=191 \cdot 7)$. On the other hand, the number of deaths from stomach cancer was only half that expected $(S M R=$ $53 \cdot 1$, NS). Mortality from lung cancer was significantly increased $(S M R=140 \cdot 6)$, whereas mortality from cancer of the larynx was as expected $(S M R=102 \cdot 0)$. There were two deaths from breast cancer among men, but mortality from breast cancer among women was significantly lower than expected $(S M R=54 \cdot 3)$. On the other hand, SMRs from both cancer of the cervix uteri (SMR = 283.5) and cancer of other female genital organs, which included the ovary, fallopian tube and broad ligament, vagina, vulva, and other non-specific sites $(S M R=201 \cdot 6)$, were significantly raised. There were 15 deaths due

Table 2 Observed and expected deaths by cause, SMRs and 95\% CIs for all cohort members

\begin{tabular}{|c|c|c|c|}
\hline Cause of death (based on ICD revision at time of death) & Obs & Exp & $\operatorname{SMR}(95 \% C I)$ \\
\hline $\begin{array}{l}\text { All causes of death } \\
\text { All malignant neoplasms } \\
\text { Cancer of buccal cavity and pharynx } \\
\text { Cancer of digestive organs and peritoneum } \\
\text { Cancer of oesophagus } \\
\text { Cancer of stomach } \\
\text { Cancer of large intestine } \\
\text { Cancer of biliary passages and liver } \\
\text { Cancer of pancreas } \\
\text { Cancer of respiratory system } \\
\text { Cancer of larynx } \\
\text { Cancer of bronchus, trachea, lung } \\
\text { Cancer of all other respiratory system } \\
\text { Cancer of breast } \\
\text { All uterine cancers (women only) } \\
\text { Cancer of cervix uteri (women only) } \\
\text { Cancer of other female genital organs } \\
\text { Cancer of prostate (men only) } \\
\text { Cancer of testes and other male genital organs } \\
\text { Cancer of kidney } \\
\text { Cancer of bladder and other urinary organs } \\
\text { Cancer of central nervous system } \\
\text { Cancer of all lymphatic, haematopoietic tissues } \\
\text { Lymphosarcoma and reticulosarcoma } \\
\text { Hodgkin's disease } \\
\text { Leukaemia and aleukaemia } \\
\text { Cancer of all other lymphopoietic tissue } \\
\text { Diabetes mellitus } \\
\text { Cerebrovascular disease } \\
\text { All heart disease } \\
\text { Ischaemic heart disease } \\
\text { Chronic endocardial disease; } \\
\text { other myocardial insufficiency } \\
\text { Hypertension with heart disease } \\
\text { All other heart disease } \\
\text { Non-malignant respiratory disease } \\
\text { Influenza and pneumonia } \\
\text { Bronchitis, emphysema, asthma } \\
\text { Other non-malignant respiratory disease } \\
\text { Cirrhosis of liver } \\
\text { All external causes of death } \\
\text { Accidents } \\
\text { Motor vehicle accidents } \\
\text { Homicides and other external causes } \\
\text { Unknown causes (in all causes category only) }\end{array}$ & $\begin{array}{r}1628 \\
425 \\
6 \\
90 \\
14 \\
6 \\
36 \\
8 \\
19 \\
168 \\
4 \\
162 \\
2 \\
14 \\
11 \\
10 \\
13 \\
19 \\
2 \\
15 \\
5 \\
8 \\
31 \\
4 \\
4 \\
11 \\
12 \\
16 \\
71 \\
489 \\
398 \\
16 \\
18 \\
52 \\
97 \\
23 \\
23 \\
51 \\
38 \\
301 \\
183 \\
116 \\
49 \\
42\end{array}$ & $\begin{array}{r}1509 \cdot 48 \\
367 \cdot 86 \\
8 \cdot 96 \\
81 \cdot 87 \\
7 \cdot 30 \\
11 \cdot 29 \\
30 \cdot 39 \\
6 \cdot 64 \\
16 \cdot 78 \\
120 \cdot 62 \\
3 \cdot 92 \\
115 \cdot 19 \\
1 \cdot 51 \\
22 \cdot 43 \\
5 \cdot 57 \\
3 \cdot 53 \\
6 \cdot 45 \\
13 \cdot 61 \\
2 \cdot 44 \\
8 \cdot 56 \\
6 \cdot 30 \\
13 \cdot 63 \\
37 \cdot 73 \\
5 \cdot 53 \\
4 \cdot 46 \\
14 \cdot 81 \\
12 \cdot 93 \\
22 \cdot 70 \\
63 \cdot 72 \\
483 \cdot 92 \\
383 \cdot 97 \\
12 \cdot 69 \\
9 \cdot 68 \\
67 \cdot 75 \\
80 \cdot 18 \\
25 \cdot 85 \\
18 \cdot 05 \\
36 \cdot 28 \\
46 \cdot 88 \\
265 \cdot 81 \\
166 \cdot 44 \\
93 \cdot 59 \\
35 \cdot 56\end{array}$ & $\begin{array}{c}107 \cdot 9^{\star \star}(102 \cdot 7-113 \cdot 2) \\
115 \cdot 5^{\star \star}(104 \cdot 8-127 \cdot 1) \\
67 \cdot 0(24 \cdot 6-145 \cdot 8) \\
109 \cdot 9(88 \cdot 4-135 \cdot 1) \\
191 \cdot 7^{\star}(104 \cdot 8-321 \cdot 7) \\
53 \cdot 1(19 \cdot 5-115 \cdot 7) \\
118 \cdot 4(83 \cdot 0-164 \cdot 0) \\
120 \cdot 5(52 \cdot 0-237 \cdot 4) \\
113 \cdot 2(68 \cdot 2-176 \cdot 8) \\
139 \cdot 3^{\star \star}(119 \cdot 0-162 \cdot 0) \\
102 \cdot 0(27 \cdot 8-261 \cdot 2) \\
140 \cdot 6^{\star \star}(119 \cdot 8-164 \cdot 0) \\
132 \cdot 8(16 \cdot 1-479 \cdot 7) \\
62 \cdot 4(34 \cdot 1-104 \cdot 7) \\
197 \cdot 3(98 \cdot 5-353 \cdot 1) \\
283 \cdot 5^{\star \star}(135 \cdot 9-521 \cdot 3) \\
201 \cdot 6^{\star}(107 \cdot 4-344 \cdot 8) \\
139 \cdot 6(84 \cdot 0-218 \cdot 0) \\
82 \cdot 1(9 \cdot 9-296 \cdot 7) \\
175 \cdot 2(98 \cdot 1-289 \cdot 0) \\
79 \cdot 3(25 \cdot 8-185 \cdot 1) \\
58 \cdot 7(25 \cdot 3-115 \cdot 6) \\
82 \cdot 2(55 \cdot 8-116 \cdot 6) \\
72 \cdot 3(19 \cdot 7-185 \cdot 0) \\
89 \cdot 7(24 \cdot 5-229 \cdot 7) \\
74 \cdot 3(37 \cdot 1-132 \cdot 9) \\
92 \cdot 8(48 \cdot 0-162 \cdot 1) \\
70 \cdot 5(40 \cdot 3-114 \cdot 5) \\
111 \cdot 4(87 \cdot 0-140 \cdot 6) \\
101 \cdot 0(92 \cdot 3-110 \cdot 4) \\
103 \cdot 7(93 \cdot 7-114 \cdot 4) \\
126 \cdot 1(72 \cdot 1-204 \cdot 8) \\
185 \cdot 9 \star(110 \cdot 2-293 \cdot 8) \\
76 \cdot 8(57 \cdot 3-100 \cdot 7) \\
121 \cdot 0(98 \cdot 1-147 \cdot 6) \\
89 \cdot 0(56 \cdot 4-133 \cdot 5) \\
127 \cdot 4(80 \cdot 8-191 \cdot 2) \\
140 \cdot 6^{\star}(104 \cdot 7-184 \cdot 8) \\
81 \cdot 1(57 \cdot 4-111 \cdot 3) \\
113 \cdot 2^{\star}(100 \cdot 8-126 \cdot 8) \\
109 \cdot 9(94 \cdot 6-127 \cdot 1) \\
123 \cdot 9^{\star}(102 \cdot 4-148 \cdot 7) \\
137 \cdot 8^{\star}(101 \cdot 9-182 \cdot 2)\end{array}$ \\
\hline
\end{tabular}

${ }^{\star} \mathrm{p}<0.05 ;{ }^{\star \star} \mathrm{p}<0.01$. No of persons $=15$ 826; Person-years $=307932$. 
Table 3 Observed deaths and SMRs by cause and latency for all cohort memberst

\begin{tabular}{|c|c|c|c|c|c|c|}
\hline \multirow[b]{2}{*}{ Cause of death (based on ICD revision at time of death) } & \multicolumn{2}{|c|}{$<10$ years } & \multicolumn{2}{|c|}{$10-19$ years } & \multicolumn{2}{|c|}{$\geqslant 20$ years } \\
\hline & Obs & $S M R$ & Obs & $S M R$ & Obs & $S M R$ \\
\hline All causes of death & 427 & $98 \cdot 0$ & 659 & $109 \cdot 0^{\star}$ & 542 & $115 \cdot 4^{\star \star}$ \\
\hline All malignant neoplasms & 81 & $99 \cdot 8$ & 177 & $116 \cdot 3$ & 167 & $124 \cdot 1^{\star \star}$ \\
\hline Cancer of buccal cavity and pharynx & 1 & $46 \cdot 4$ & 1 & $26 \cdot 9$ & 4 & $129 \cdot 8$ \\
\hline Cancer of digestive organs and peritoneum & 16 & $93 \cdot 2$ & 35 & $103 \cdot 9$ & 39 & $125 \cdot 8$ \\
\hline Cancer of oesophagus & 2 & 143.4 & 8 & $265 \cdot 8^{\star}$ & 4 & $138 \cdot 0$ \\
\hline Cancer of stomach & 2 & $72 \cdot 6$ & 0 & - & 4 & $102 \cdot 9$ \\
\hline Cancer of large intestine & 6 & $100 \cdot 9$ & 15 & $119 \cdot 7$ & 15 & 125.9 \\
\hline Cancer of biliary passages and liver & 0 & - & 3 & $109 \cdot 6$ & 5 & $183 \cdot 6$ \\
\hline Cancer of pancreas & 5 & $145 \cdot 2$ & 6 & $86 \cdot 7$ & 8 & $124 \cdot 7$ \\
\hline Cancer of respiratory system & 25 & $109 \cdot \overline{8}$ & 73 & $145 \cdot 7^{\star \star}$ & 70 & $146 \cdot 6^{\star \star}$ \\
\hline Cancer of larynx & 2 & $231 \cdot 6$ & 1 & $61 \cdot 8$ & 1 & $69 \cdot 4$ \\
\hline Cancer of bronchus, trachea, lung & 23 & $107 \cdot 1$ & 70 & $146 \cdot 2^{\star \star}$ & 69 & $150 \cdot 5^{\star \star}$ \\
\hline Cancer of all other respiratory system & 0 & - & 2 & $320 \cdot 4$ & 0 & - \\
\hline Cancer of breast & 3 & $57 \cdot 2$ & 7 & $70 \cdot 7$ & 4 & $54 \cdot 8$ \\
\hline All uterine cancers (women only) & 3 & $171 \cdot 7$ & 4 & 173.9 & 4 & $262 \cdot 1$ \\
\hline Cancer of cervix uteri (women only) & 3 & $229 \cdot 3$ & 4 & $269 \cdot 7$ & 3 & $407 \cdot 3$ \\
\hline Cancer of other female genital organs & 3 & $200 \cdot 5$ & 3 & $110 \cdot 0$ & 7 & $314 \cdot 8^{*}$ \\
\hline Cancer of prostate (men only) & 1 & $60 \cdot 8$ & 12 & $223 \cdot 2^{\star}$ & 6 & 91.0 \\
\hline Cancer of testes and other male genital organs & 2 & $137 \cdot 5$ & 0 & - & 0 & - \\
\hline Cancer of kidney & 3 & $166 \cdot 6$ & 5 & $140 \cdot 7$ & 7 & $218 \cdot 2$ \\
\hline Cancer of bladder and other urinary organs & 3 & $253 \cdot 4$ & 0 & - & 2 & $78 \cdot 3$ \\
\hline Cancer of central nervous system & 1 & $24 \cdot 5$ & 6 & $105 \cdot 2$ & 1 & $26 \cdot 0$ \\
\hline Cancer of all lymphatic, haematopoietic tissues & 9 & 80.9 & 10 & $66 \cdot 2$ & 12 & $104 \cdot 4$ \\
\hline Lymphosarcoma and reticulosarcoma & 1 & $47 \cdot 1$ & 1 & $45 \cdot 8$ & 2 & $162 \cdot 6$ \\
\hline Hodgkin's disease & 3 & $128 \cdot 5$ & 1 & $64 \cdot 2$ & 0 & - \\
\hline Leukaemia and aleukaemia & 5 & 110.9 & 4 & $67 \cdot 6$ & 2 & $45 \cdot 7$ \\
\hline Cancer of all other lymphopoietic tissue & 0 & - & 4 & $73 \cdot 4$ & 8 & $150 \cdot 4$ \\
\hline Diabetes mellitus & 4 & $71 \cdot 3$ & 3 & $32 \cdot 1^{\star}$ & 9 & 116.4 \\
\hline Cerebrovascular disease & 22 & $139 \cdot 9$ & 31 & 120.9 & 18 & $80 \cdot 5$ \\
\hline All heart disease & 97 & $85 \cdot 4$ & 200 & $101 \cdot 3$ & 192 & $111 \cdot 1$ \\
\hline Ischaemic heart disease & 86 & 89.8 & 164 & $104 \cdot 2$ & 148 & $113 \cdot 1$ \\
\hline \multicolumn{7}{|l|}{ Chronic endocardial disease; } \\
\hline other myocardial insufficiency & 1 & $60 \cdot 9$ & 6 & $124 \cdot 7$ & 9 & $144 \cdot 4$ \\
\hline Hypertension with heart disease & 4 & $187 \cdot 9$ & 6 & $157 \cdot 1$ & 8 & $214 \cdot 2$ \\
\hline All other heart disease & 5 & $51 \cdot 1$ & 22 & $79 \cdot 1$ & 25 & 83.0 \\
\hline Non-malignant respiratory disease & 11 & $65 \cdot 4$ & 40 & $127 \cdot 3$ & 46 & $144 \cdot 0^{*}$ \\
\hline Influenza and pneumonia & 3 & 42.5 & 8 & $81 \cdot 3$ & 12 & $134 \cdot 2$ \\
\hline Bronchitis, emphysema, asthma & 6 & $126 \cdot 6$ & 7 & $96 \cdot 4$ & 10 & $165 \cdot 4$ \\
\hline Other non-malignant respiratory disease & 2 & 39.9 & 25 & $174 \cdot 6^{\star}$ & 24 & $141 \cdot 6$ \\
\hline Cirrhosis of liver & 8 & $57 \cdot 3$ & 17 & $83 \cdot 2$ & 13 & $104 \cdot 3$ \\
\hline All external causes of death & 143 & $103 \cdot 6$ & 119 & $125 \cdot 6^{\star}$ & 39 & $118 \cdot 0$ \\
\hline Accidents & 95 & $103 \cdot 6$ & 67 & $120 \cdot 7$ & 21 & $109 \cdot 1$ \\
\hline Motor vehicle accidents & 65 & 116.5 & 38 & $131 \cdot 0$ & 13 & $148 \cdot 2$ \\
\hline Homicides and other external causes & 25 & $141 \cdot 3$ & 20 & $143 \cdot 5$ & 4 & $101 \cdot 8$ \\
\hline Unknown causes (in all causes category only) & 24 & & 14 & & 4 & \\
\hline
\end{tabular}

to kidney cancer compared with 8.56 expected $\quad(\mathrm{SMR}=175 \cdot 2, \quad 95 \% \quad \mathrm{CI}$ $98 \cdot 1-289 \cdot 0)$. Both male and female workers showed a similar increase in kidney cancer. There were 31 deaths from cancer of the lympathic and haematopoietic tissues, lower than the $37 \cdot 73$ expected $(S M R=82 \cdot 2)$. All four subcategories of haematological malignancies showed a non-significant deficit. In particular, there were 11 deaths due to leukaemia, whereas $14 \cdot 81$ were expected $(S M R=74 \cdot 3)$.

For all heart disease, the number of deaths was slightly above those expected (489v 483.92). The SMR for hypertensive heart disease of 185.9 was statistically significant. Mortality from all non-malignant respiratory diseases was increased $(S M R=121 \cdot 0)$, and the excess was close to being statistically significant. The SMR for other non-malignant respiratory disease was 140.6 and was statistically significant. Mortality from all external causes was significantly increased $(S M R=$ 113.2). The excess came primarily from motor vehicle accidents $(S M R=123.9)$ and homicides $(S M R=137 \cdot 8)$.

Table 3 shows the cause specific mortality patterns by latency (time since first exposure to styrene). In the $<10$ year latency group, there were several increases in mortality, including from oesphageal cancer, pancreatic cancer, laryngeal cancer, cancer of the cervix uteri, cancer of other female organs, kidney cancer, bladder cancer, cerebrovascular dis- ease, hypertensive heart disease, bronchitis, emphysema, asthma, and homicides. None of the increases was statistically significant. For the groups with $10-19$ and $\geqslant 20$ years of latency, some causes of death showed significant increases, including overall mortality and lung cancer. For the 10-19 year latency group, SMRs for oesophageal cancer, prostate cancer, and other non-malignant respiratory disease were significantly increased. Mortality from cancer of other female genital organs was highest among those with $\geqslant 20$ years of latency.

Table 4 presents the analysis by duration of employment. No upward trend was detected for any cause of death. Most of the mortality increases occurred among workers who had worked in the reinforced plastics industry for only six months to a year. For example, the highest SMRs for overall mortality, all cancers, lung cancer, cancer of the cervix uteri, all heart disease, ischaemic heart disease, other non-malignant respiratory diseases, and homicides were all reported among workers employed for six months to a year, and most of these SMRs were significant. On the other hand, no significantly raised SMRs were reported in either the $5-9.9$ or $\geqslant 10$ year group. For most causes, there was a general tendency for lower SMRs to be associated with a longer duration of employment in the reinforced plastics industry.

A similar analysis based on duration of exposure to styrene was also performed (table 
Table 4 Observed deaths and SMRs by cause and duration of employment for all cohort members

\begin{tabular}{|c|c|c|c|c|c|c|c|c|c|c|}
\hline \multirow[b]{2}{*}{ Cause of death (based on ICD revision at time of death) } & \multicolumn{2}{|c|}{$<1$ year } & \multicolumn{2}{|c|}{$1-1.9$ years } & \multicolumn{2}{|c|}{$2-4.9$ years } & \multicolumn{2}{|c|}{$5-9.9$ years } & \multicolumn{2}{|c|}{$\geqslant 10$ years } \\
\hline & Obs & $S M R$ & Obs & $S M R$ & Obs & $S M R$ & Obs & $S M R$ & Obs & $S M R$ \\
\hline All causes of death & 389 & $129 \cdot 7^{\star \star}$ & 312 & $110 \cdot 6$ & 405 & $114 \cdot 0^{\star}$ & 233 & $91 \cdot 2$ & 289 & $91 \cdot 2$ \\
\hline All malignant neoplasms & 93 & $140 \cdot 2^{\star \star}$ & 75 & $115 \cdot 3$ & 107 & $126 \cdot 7^{\star}$ & 63 & 95.6 & 87 & $101 \cdot 0$ \\
\hline Cancer of buccal cavity and pharynx & 2 & $126 \cdot 0$ & 0 & - & 1 & $49 \cdot 4$ & 1 & $62 \cdot 8$ & 2 & $92 \cdot 2$ \\
\hline Cancer of digestive organs and peritoneum & 18 & $127 \cdot 2$ & 19 & $135 \cdot 8$ & 15 & 80.9 & 10 & $67 \cdot 3$ & 28 & $137 \cdot 7$ \\
\hline Cancer of oesophagus & 2 & $159 \cdot 7$ & 3 & $238 \cdot 5$ & 4 & $248 \cdot 3$ & 1 & $76 \cdot 8$ & 4 & $212 \cdot 8$ \\
\hline Cancer of stomach & $\overline{1}$ & $50 \cdot 3$ & 1 & $50 \cdot 8$ & 1 & $38 \cdot 5$ & 0 & - & 3 & $111 \cdot 1$ \\
\hline Cancer of large intestine & 5 & $95 \cdot 8$ & 8 & $155 \cdot 6$ & 4 & $58 \cdot 3$ & 7 & $126 \cdot 2$ & 12 & 157.5 \\
\hline Cancer of biliary passages and liver & 1 & $86 \cdot 2$ & 2 & $175 \cdot 8$ & 1 & $67 \cdot 0$ & 1 & $83 \cdot 4$ & 3 & $181 \cdot 6$ \\
\hline Cancer of pancreas & 6 & $209 \cdot 0$ & 3 & $105 \cdot 2$ & 5 & $132 \cdot 6$ & 0 & - & 5 & $118 \cdot 2$ \\
\hline Cancer of respiratory system & 39 & $188 \cdot 7^{\star \star}$ & 26 & $124 \cdot \overline{8}$ & 45 & $168 \cdot 7^{\star \star}$ & 29 & $133 \cdot 7$ & 29 & $94 \cdot 3$ \\
\hline Cancer of larynx & 3 & 452.9 & 1 & $148 \cdot 6$ & 0 & - & 0 & - & 0 & - \\
\hline Cancer of bronchus, trachea, lung & 36 & $182 \cdot 7^{\star \star}$ & 25 & $125 \cdot 8$ & 45 & $176 \cdot 8^{\star \star}$ & 28 & $135 \cdot 1$ & 28 & $95 \cdot 2$ \\
\hline Cancer of all other respiratory system & 0 & - & 0 & - & 0 & - & 1 & $391 \cdot 6$ & 1 & $318 \cdot 3$ \\
\hline Cancer of breast & 3 & 72.9 & 3 & $74 \cdot 6$ & 3 & $52 \cdot 1$ & 4 & $89 \cdot 9$ & 1 & $24 \cdot 5$ \\
\hline All uterine cancers (women only) & 5 & $468 \cdot 6^{\star \star}$ & 1 & $99 \cdot 8$ & 3 & 203.9 & 0 & - & 2 & $209 \cdot 7$ \\
\hline Cancer of cervix uteri (women only) & 4 & $553 \cdot 0^{\star}$ & 1 & $147 \cdot 0$ & 3 & $309 \cdot 7$ & 0 & - & 2 & $404 \cdot 2$ \\
\hline Cancer of other female genital organs & 1 & $88 \cdot 6$ & 1 & $90 \cdot 8$ & 5 & $307 \cdot 1$ & 2 & $152 \cdot 8$ & 4 & $312 \cdot 6$ \\
\hline Cancer of prostate (men only) & 5 & $249 \cdot 8$ & 1 & $48 \cdot 9$ & 5 & 173.5 & 4 & $157 \cdot 0$ & 4 & 96.7 \\
\hline Cancer of testes and other male genital organs & 1 & $145 \cdot 5$ & 1 & $170 \cdot 2$ & 0 & - & 0 & - & 0 & - \\
\hline Cancer of kidney & 3 & $194 \cdot 4$ & 3 & $197 \cdot 3$ & 3 & $154 \cdot 5$ & 1 & $65 \cdot 9$ & 5 & $245 \cdot 3$ \\
\hline Cancer of bladder and other urinary organs & 1 & $100 \cdot 1$ & 0 & - & 2 & $144 \cdot 3$ & 2 & $171 \cdot 8$ & 0 & - \\
\hline Cancer of central nervous system & 3 & $104 \cdot 0$ & 1 & $37 \cdot 1$ & 3 & $91 \cdot 4$ & $\overline{1}$ & $44 \cdot 2$ & 0 & - \\
\hline Cancer of all lymphatic, haematopoietic tissues & 3 & $38 \cdot 6$ & 7 & $96 \cdot 7$ & 10 & $111 \cdot 6$ & 4 & $63 \cdot 4$ & 7 & 93.9 \\
\hline Lymphosarcoma and reticulosarcoma & 1 & $89 \cdot 2$ & 0 & - & 1 & $74 \cdot 6$ & 0 & - & 2 & $186 \cdot 2$ \\
\hline Hodgkin's disease & 2 & $175 \cdot 1$ & 1 & $99 \cdot 6$ & 1 & 86.5 & 0 & - & 0 & - \\
\hline Leukaemia and aleukaemia & 0 & - & 3 & $104 \cdot 2$ & 4 & $113 \cdot 2$ & 3 & $123 \cdot 0$ & 1 & $35 \cdot 2$ \\
\hline Cancer of all other lymphopoietic tissue & 0 & - & 3 & $130 \cdot 2$ & 4 & $136 \cdot 7$ & 1 & $44 \cdot 0$ & 4 & $131 \cdot 8$ \\
\hline Diabetes mellitus & 4 & $93 \cdot 6$ & 1 & $24 \cdot 6$ & 4 & $75 \cdot 1$ & 2 & $50 \cdot 0$ & 5 & $99 \cdot 4$ \\
\hline Cerebrovascular disease & 15 & $136 \cdot 6$ & 10 & $94 \cdot 8$ & 16 & $107 \cdot 0$ & 10 & $85 \cdot 8$ & 20 & $128 \cdot 4$ \\
\hline All heart disease & 104 & $124 \cdot 1^{\star}$ & 85 & $103 \cdot 1$ & 120 & $109 \cdot 2$ & 76 & $87 \cdot 3$ & 104 & $86 \cdot 2$ \\
\hline Ischaemic heart disease & 87 & $132 \cdot 7^{\star}$ & 72 & 110.9 & 95 & $108 \cdot 9$ & 62 & $89 \cdot 3$ & 82 & $84 \cdot 7$ \\
\hline \multicolumn{11}{|l|}{ Chronic endocardial disease; } \\
\hline other myocardial insufficiency & 2 & $91 \cdot 6$ & 2 & 96.9 & 7 & $249 \cdot 0^{\star}$ & 2 & $87 \cdot 1$ & 3 & $90 \cdot 1$ \\
\hline Hypertension with heart disease & 5 & $295 \cdot 4$ & 1 & $60 \cdot 3$ & 5 & $221 \cdot 6$ & 2 & $113 \cdot 3$ & 5 & $216 \cdot 4$ \\
\hline All other heart disease & 9 & $72 \cdot 2$ & 8 & $67 \cdot 1$ & 13 & $85 \cdot 5$ & 9 & $76 \cdot 3$ & 13 & $79 \cdot 4$ \\
\hline Non-malignant respiratory disease & 20 & 145.9 & 17 & $127 \cdot 4$ & 21 & $116 \cdot 5$ & 19 & $130 \cdot 9$ & 20 & $97 \cdot 2$ \\
\hline Influenza and pneumonia & 3 & $62 \cdot 3$ & 6 & 133.6 & 6 & $97 \cdot 7$ & 3 & $66 \cdot 2$ & 5 & $85 \cdot 2$ \\
\hline Bronchitis, emphysema, asthma & 6 & $204 \cdot 2$ & 3 & $101 \cdot 1$ & 4 & $97 \cdot 8$ & 5 & $149 \cdot 3$ & 5 & $106 \cdot 3$ \\
\hline Other non-malignant respiratory disease & 11 & $184 \cdot 7$ & 8 & $136 \cdot 0$ & 11 & $141 \cdot 1$ & 11 & $165 \cdot 8$ & 10 & 99.9 \\
\hline Cirrhosis of liver & 6 & $63 \cdot 3$ & 9 & $99 \cdot 2$ & 11 & 97.9 & 3 & $37 \cdot 4$ & 9 & $99 \cdot 3$ \\
\hline All external causes of death & 95 & $127 \cdot 2^{\star}$ & 80 & $125 \cdot \overline{8}$ & 74 & $107 \cdot 8$ & 34 & 98.9 & 18 & 73.6 \\
\hline Accidents & 57 & $120 \cdot 0$ & 49 & $122 \cdot 0$ & 47 & $109 \cdot 4$ & 21 & $100 \cdot 0$ & 9 & $60 \cdot 7$ \\
\hline Motor vehicle accidents & 33 & $117 \cdot 5$ & 32 & 136.9 & 31 & $127 \cdot 5$ & 17 & $154 \cdot 6$ & 3 & $44 \cdot 0$ \\
\hline Homicides and other external causes & 23 & $225 \cdot 7 \star \star$ & 14 & $161 \cdot 8$ & 7 & $75 \cdot 3$ & 4 & $87 \cdot 9$ & 1 & $34 \cdot 8$ \\
\hline Unknown causes (in all causes category only) & 20 & & 9 & & 9 & & 4 & & 0 & \\
\hline
\end{tabular}

Table 5 Observed deaths and SMRs by cause and duration of exposure to styrene for all cohort members

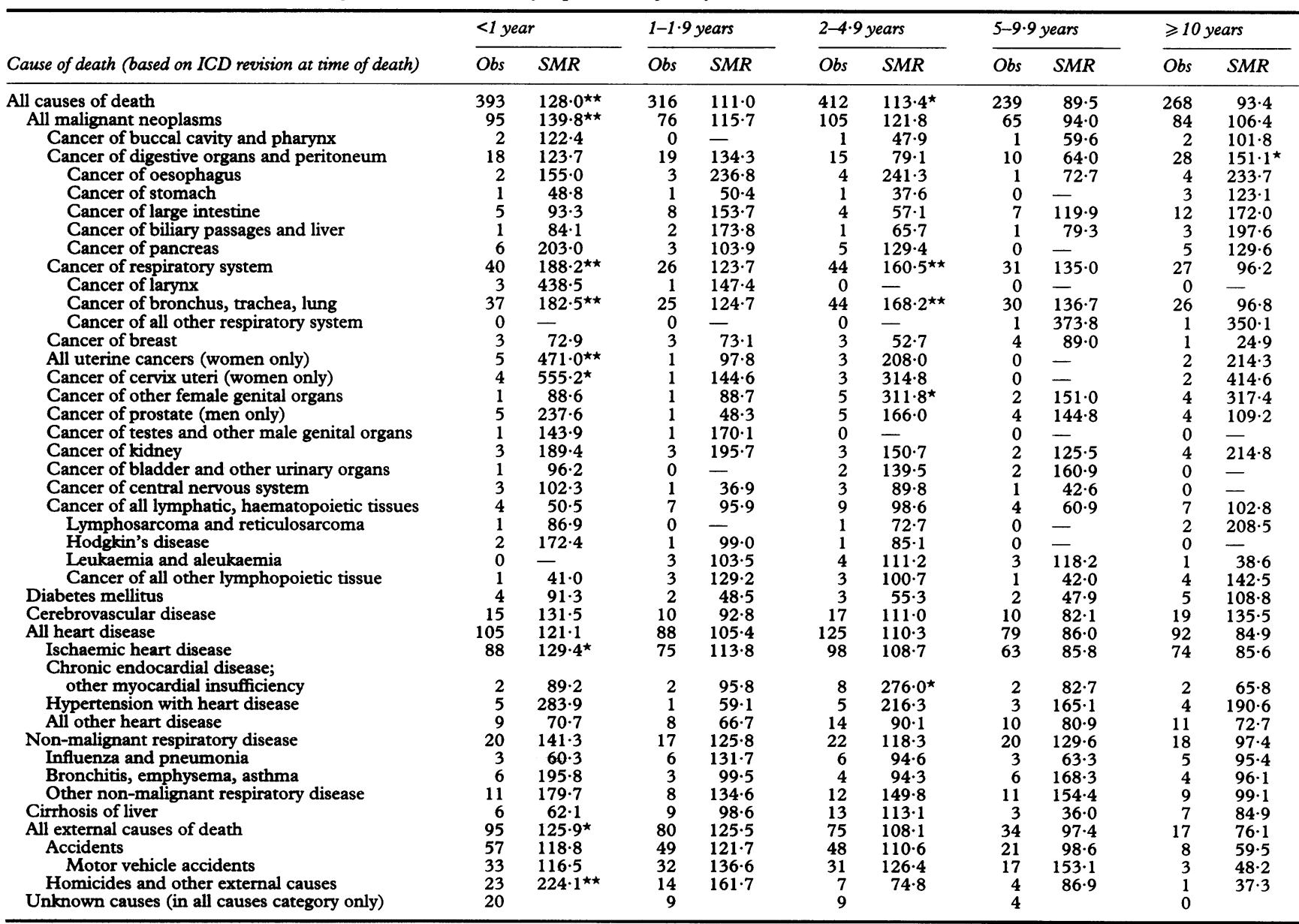


Table 6 Observed deaths and SMRs by cause and cumulative styrene exposure (ppm-years) for all cohort members

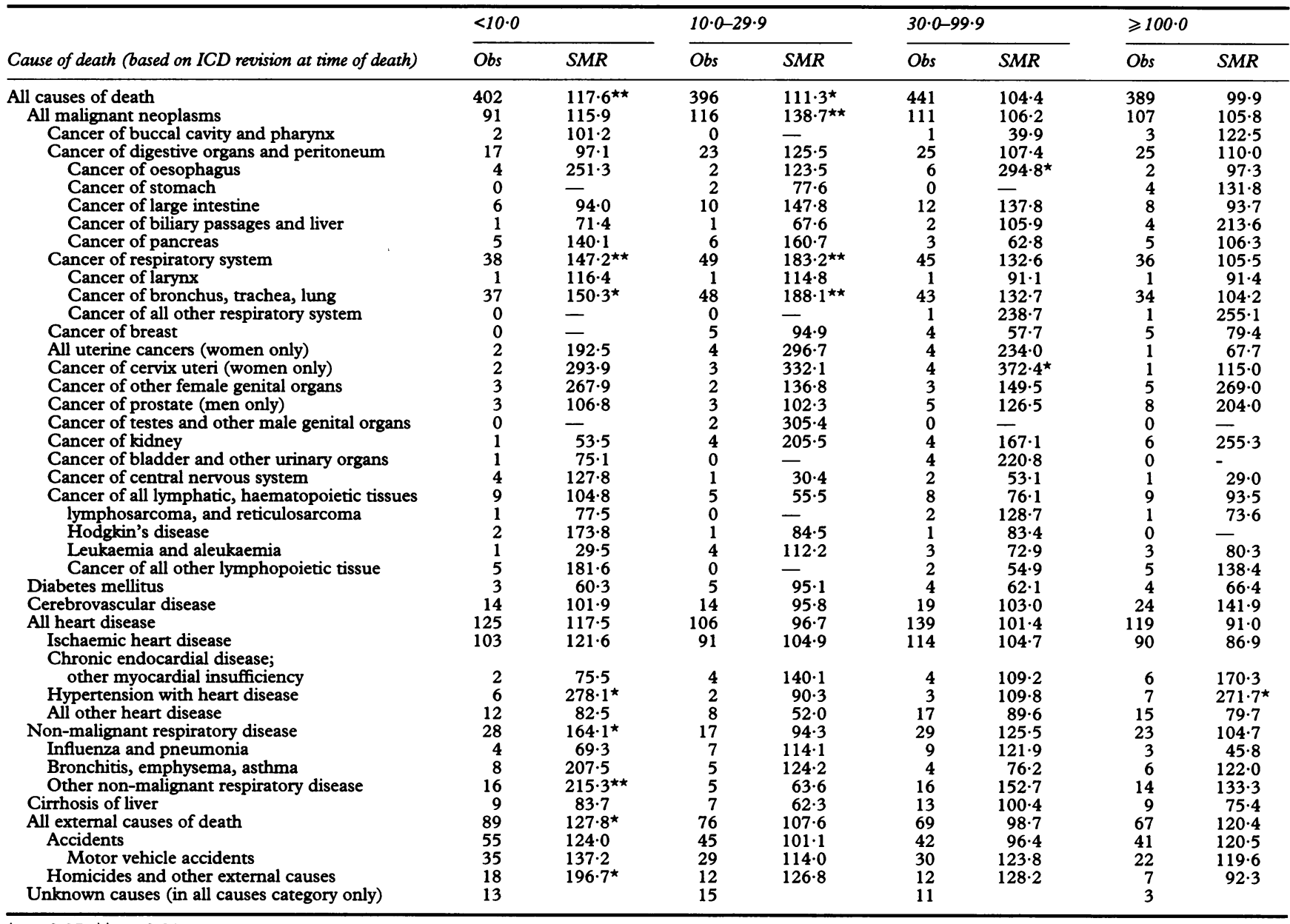

${ }^{\star} \mathrm{p}<0.05 ;{ }^{\star \star} \mathrm{p}<0.01$

5). For most of the cohort (98\%), duration of exposure was the same as duration of employment. Therefore, the results presented in table 5 are similar to those in table 4. That is, the $<1$ year exposure group had the greatest number of significantly increased SMRs, and no upward trend was detected for any cause. In particular, there was no exposure-response relation for lymphatic and haematopoietic cancers overall, or for any of the specific subcategories of haematological maligancies.

Table 6 shows the analysis based on cumulative exposure. The categories were chosen to approximate quartiles in the distribution of cumulative exposure. The highest cumulative exposure experienced was 2633 ppm-years attained by a worker whose duration of exposure was 12.5 years. This employee was engaged in the lay up and spray up process, and he was an active employee on 31 December 1977. In the $\geqslant 100$ ppm-year group, the average cumulative exposure was 298 ppm-years.

No significant increase in mortality was found for the highest $\geqslant 100$ ppm-years) cumulative exposure group, except for hypertensive heart disease. On the other hand, the lowest ( $<10$ ppm-years) cumulative exposure group showed a greater number of significant cause specific mortality excesses. For example, both the $<10$ ppm-year and the 10-29.9 ppm-year groups showed significant excesses in overall mortality, whereas overall mortality in the two groups with higher cumulative exposure (30-99.9 and $\geqslant 100$ ppm-years) was similar to that expected. Similarly, significant lung cancer SMRs were only found for the two groups with low cumulative exposure ( $<10$ and 10-29.9 ppm-years). In particular, there was no upward trend for any of the specific categories of hematological malignancies with increasing cumulative exposure.

Cause specific mortality patterns by cumulative exposure were further examined in relation to latency, and no association was found. Particularly, no association was found between cumulative exposure to styrene and all lymphatic and haematopoietic cancers (or leukaemia), even among workers with more than 20 years of latency (table 7).

Analyses were also performed with the six process categories described earlier. Within each category, workers were classified by duration of employment: never, $\leqslant 1$ year, $1-2$ years, and $>2$ years. There was no upward trend for any cause specific mortality by duration of employment in any of the categories. To save space, we only present results for those employed for more than two years in each category (table 8). No significant increase was found for any cause of death in this group in any of the categories, with the exception of cancer of the biliary passages and liver for plant office and support and lung cancer for maintenance and preparation. On the other hand, several mortality excesses 
Table 7 SMRs by latencyt and cumulative styrene exposure for lymphatic and haematopoietic cancers (LHC) and leukaemia

\begin{tabular}{|c|c|c|c|c|c|}
\hline \multirow[b]{2}{*}{ Latency } & \multicolumn{5}{|c|}{ Cumulative styrene exposure (ppm-years) } \\
\hline & $\begin{array}{l}<10 \cdot 0 \\
S M R(O b s / E x p)\end{array}$ & $\begin{array}{l}10 \cdot 0-29 \cdot 9 \\
S M R(O b s / E x p)\end{array}$ & $\begin{array}{l}30 \cdot 0-99 \cdot 9 \\
S M R(O b s / E x p)\end{array}$ & $\begin{array}{l}\geqslant 100 \dagger \\
S M R(O b s / E x p)\end{array}$ & $\begin{array}{l}\text { Total } \\
\text { SMR (Obs/Exp) }\end{array}$ \\
\hline $\begin{array}{l}\text { < } 10 \text { years: } \\
\text { LHC } \\
\text { Leukaemia } \\
\text { 10-19 years: }\end{array}$ & $\begin{array}{r}32.9(1 / 3.04) \\
-(0 / 1 \cdot 24)\end{array}$ & $\begin{array}{l}123 \cdot 6(4 / 3 \cdot 24) \\
228 \cdot 5(3 / 1 \cdot 31)\end{array}$ & $\begin{array}{l}99 \cdot 7(3 / 3 \cdot 01) \\
82 \cdot 5(1 / 1 \cdot 21)\end{array}$ & $\begin{array}{r}54 \cdot 1(1 / 1 \cdot 85) \\
133.6(1 / 0 \cdot 75)\end{array}$ & $\begin{array}{r}80.9(9 / 11 \cdot 13) \\
110.9(5 / 4.51)\end{array}$ \\
\hline $\begin{array}{l}\text { LHC } \\
\text { Leukaemia } \\
\geqslant 20 \text { years: }\end{array}$ & $\begin{array}{r}95 \cdot 2(3 / 3 \cdot 15) \\
-(0 / 1 \cdot 24)\end{array}$ & $\begin{array}{l}28 \cdot 9(1 / 3.46) \\
72 \cdot 8(1 / 1 \cdot 37)\end{array}$ & $\begin{array}{l}67 \cdot 5(3 / 4 \cdot 45) \\
57 \cdot 6(1 / 1 \cdot 74)\end{array}$ & $\begin{array}{r}74 \cdot 2(3 / 4 \cdot 05) \\
127 \cdot 2(2 / 1 \cdot 57)\end{array}$ & $\begin{array}{l}66 \cdot 2(10 / 15 \cdot 11) \\
67 \cdot 6(4 / 5 \cdot 92)\end{array}$ \\
\hline $\begin{array}{l}\text { LHC } \\
\text { Leukaemia } \\
\text { Total: }\end{array}$ & $\begin{array}{l}208 \cdot 4(5 / 2 \cdot 40) \\
109 \cdot 2(1 / 0 \cdot 92)\end{array}$ & $\begin{array}{l}-(0 / 2 \cdot 30) \\
-(0 / 0 \cdot 88)\end{array}$ & $\begin{array}{l}65 \cdot 4(2 / 3 \cdot 06) \\
85 \cdot 1(1 / 1 \cdot 17)\end{array}$ & $\begin{array}{r}133.9(5 / 3 \cdot 73) \\
-(0 / 1 \cdot 41)\end{array}$ & $\begin{array}{c}104 \cdot 4(12 / 11 \cdot 50) \\
45 \cdot 7(2 / 4 \cdot 38)\end{array}$ \\
\hline $\begin{array}{l}\text { LHC } \\
\text { Leukaemia }\end{array}$ & $\begin{array}{r}104 \cdot 8(9 / 8 \cdot 59) \\
29 \cdot 5(1 / 3 \cdot 39)\end{array}$ & $\begin{array}{r}55 \cdot 5(5 / 9 \cdot 00) \\
112 \cdot 2(4 / 3 \cdot 56)\end{array}$ & $\begin{array}{l}76 \cdot 1(8 / 10 \cdot 51) \\
72 \cdot 9(3 / 4 \cdot 12)\end{array}$ & $\begin{array}{l}93.5(9 / 9.63) \\
80.3(3 / 3.73)\end{array}$ & $\begin{array}{l}82 \cdot 2(31 / 37 \cdot 73) \\
74 \cdot 3(11 / 14 \cdot 81)\end{array}$ \\
\hline
\end{tabular}

${ }^{\star} \mathrm{p}<0.05 ;{ }^{\star \star} \mathrm{p}<0.01$. †Time since first exposure to styrene.

occurred among short term $(<2$ years $)$ employees in these process categories.

Because the OCMAP program does not provide any analysis for non-Hodgkin's lymphoma or multiple myeloma, these sites were evaluated by a separate program with 1950-80 United States age specific rates compiled by the National Cancer Institute. ${ }^{12}$ It should be noted that the use of 1950-80 rates might have slightly underestimated the expected deaths for the later years, 1981-9.
No significant increase in mortality from either non-Hodgkin's lymphoma or multiple myeloma was found. For non-Hodgkin's lymphoma, 10 deaths were reported compared with 12.41 expected. The corresponding SMR was 80.6 (95\% CI $38 \cdot 8-148 \cdot 2)$. Six deaths were from multiple myeloma compared with 4.47 expected. The SMR was slightly increased (SMR $=133.9$ 95\% CI 49.0-291·7), but the increase was not significant.

Data for selected causes of death were also

Table 8 Observed deaths and SMRs by cause among cohort members employed more than two years in the six processing categories

\begin{tabular}{|c|c|c|c|c|c|c|c|c|c|c|c|c|}
\hline \multirow{2}{*}{$\begin{array}{l}\text { Cause of death (based on ICD } \\
\text { revision at the time of death) }\end{array}$} & \multicolumn{2}{|c|}{$\begin{array}{l}\text { Category } 1 \\
>2 \text { years }\end{array}$} & \multicolumn{2}{|c|}{$\begin{array}{l}\text { Category } 2 \\
>2 \text { years }\end{array}$} & \multicolumn{2}{|c|}{$\begin{array}{l}\text { Category } 3 \\
>2 \text { years }\end{array}$} & \multicolumn{2}{|c|}{$\begin{array}{l}\text { Category } 4 \\
>2 \text { years }\end{array}$} & \multicolumn{2}{|c|}{$\begin{array}{l}\text { Category } 5 \\
>2 \text { years }\end{array}$} & \multicolumn{2}{|c|}{$\begin{array}{l}\text { Category } 6 \\
>2 \text { years }\end{array}$} \\
\hline & Obs & $S M R$ & Obs & $S M R$ & Obs & $S M R$ & $O b s$ & SMR & Obs & $S M R$ & Obs & $S M R$ \\
\hline \multirow{2}{*}{$\begin{array}{l}\text { All causes of death } \\
\text { All malignant neoplasms }\end{array}$} & 118 & 105.0 & 109 & $103 \cdot 6$ & 246 & $94 \cdot 2$ & 188 & $100 \cdot 1$ & 233 & 99.9 & 66 & $79 \cdot 1$ \\
\hline & 28 & $100 \cdot 5$ & 32 & 109.0 & 76 & $108 \cdot 1$ & 45 & $94 \cdot 0$ & 66 & $111 \cdot 2$ & 20 & $97 \cdot 4$ \\
\hline Cancer of buccal cavity and pharynx & 0 & - & 0 & - & 0 & - & 2 & $162 \cdot 8$ & 2 & $131 \cdot 7$ & 1 & $171 \cdot 5$ \\
\hline \multirow{6}{*}{$\begin{array}{l}\text { Cancer of digestive organs and } \\
\text { peritoneum } \\
\text { Cancer of oesophagus } \\
\text { Cancer of stomach } \\
\text { Cancer of large intestine } \\
\text { Cancer of biliary passages and liver } \\
\text { Cancer of pancreas }\end{array}$} & 8 & $131 \cdot 1$ & 8 & $130 \cdot 4$ & 18 & $114 \cdot 6$ & 9 & $82 \cdot 2$ & 11 & $77 \cdot 1$ & 5 & $101 \cdot 9$ \\
\hline & 2 & $356 \cdot 6$ & 0 & $\overline{0}$ & 4 & $300 \cdot 6$ & 1 & $98 \cdot 3$ & 3 & $230 \cdot 2$ & 1 & $199 \cdot 1$ \\
\hline & 2 & $241 \cdot 8$ & 2 & $258 \cdot 8$ & 1 & $48 \cdot 6$ & 0 & - & 0 & $-\overline{112,6}$ & 1 & $143 \cdot 0$ \\
\hline & 2 & $88 \cdot 1$ & 2 & $83 \cdot 1$ & 9 & $149 \cdot 7$ & 3 & $74 \cdot 6$ & 6 & $113 \cdot 6$ & 2 & 114.6 \\
\hline & 0 & - & 1 & $191 \cdot 4$ & 1 & 76.9 & 4 & $456 \cdot 4^{\star}$ & 1 & $88 \cdot 7$ & 0 & - \\
\hline & 1 & $79 \cdot 5$ & 2 & 157.2 & 3 & $92 \cdot 8$ & 1 & 43.9 & 1 & $34 \cdot 2$ & 0 & - \\
\hline \multirow{2}{*}{$\begin{array}{l}\text { Cancer of respiratory system } \\
\text { Cancer of larynx }\end{array}$} & 8 & $85 \cdot 8$ & 11 & $131 \cdot 3$ & 32 & $141 \cdot 6$ & 17 & $102 \cdot 4$ & 30 & $142 \cdot 6$ & 5 & $63 \cdot 2$ \\
\hline & 0 & - & 0 & - & 0 & - & 0 & & 0 & - & 0 & - \\
\hline \multirow{2}{*}{$\begin{array}{l}\text { Cancer of bronchus, trachea, lung } \\
\text { Cancer of all other respiratory system }\end{array}$} & 8 & $89 \cdot 8$ & 10 & $124 \cdot 4$ & 31 & $143 \cdot 4$ & 17 & $107 \cdot 2$ & 30 & $149 \cdot 4^{\star}$ & 5 & $66 \cdot 2$ \\
\hline & 0 & - & 1 & $951 \cdot 8$ & 1 & $390 \cdot 6$ & 0 & - & 0 & - & 0 & - \\
\hline \multirow{2}{*}{$\begin{array}{l}\text { Cancer of breast } \\
\text { All uterine cancers (women only) }\end{array}$} & 0 & - & 2 & 55.4 & 5 & $87 \cdot 6$ & 2 & $84 \cdot 2$ & 0 & - & 0 & - \\
\hline & 1 & $264 \cdot 2$ & 2 & $228 \cdot 4$ & 1 & $72 \cdot 6$ & 0 & - & 1 & $182 \cdot 0$ & 0 & - \\
\hline $\begin{array}{l}\text { All uterine cancers (women only) } \\
\text { Cancer of cervix uteri (women only) }\end{array}$ & 1 & $420 \cdot 6$ & 2 & $381 \cdot 1$ & 1 & $121 \cdot 5$ & 0 & - & 1 & $324 \cdot 7$ & 0 & - \\
\hline \multirow{2}{*}{$\begin{array}{l}\text { Cancer of other female genital organs } \\
\text { Cancer of prostate (men only) }\end{array}$} & 0 & - & 2 & 185.4 & 3 & $177 \cdot 2$ & 2 & 277.9 & 1 & $148 \cdot 4$ & 1 & 2363.9 \\
\hline & 0 & - & 0 & - & 4 & $145 \cdot 7$ & 4 & 223.9 & 6 & 182.9 & 0 & - \\
\hline $\begin{array}{l}\text { Cancer of testes and } \\
\text { other male genital organs }\end{array}$ & 0 & - & 0 & - & 0 & - & 0 & - & 0 & - & 0 & - \\
\hline Cancer of kidney & 3 & $457 \cdot 1$ & 0 & - & 3 & 193.9 & 2 & $172 \cdot 0$ & 3 & $213 \cdot 6$ & 1 & $184 \cdot 7$ \\
\hline $\begin{array}{l}\text { Cancer of bladder and } \\
\text { other urinary organs }\end{array}$ & 0 & - & 1 & $271 \cdot 0$ & 2 & $161 \cdot 9$ & 0 & - & 0 & - & 0 & - \\
\hline Cancer of central nervous system & 1 & $94 \cdot 8$ & 0 & - & 0 & - & 2 & $118 \cdot 4$ & 1 & $57 \cdot 3$ & 1 & $142 \cdot 3$ \\
\hline $\begin{array}{l}\text { Cancer of all lymphatic, } \\
\text { haematopoietic tissue, }\end{array}$ & 4 & $140 \cdot 8$ & 2 & $71 \cdot 4$ & 4 & $62 \cdot 0$ & 3 & $64 \cdot 7$ & 5 & $93 \cdot 2$ & 2 & $102 \cdot 2$ \\
\hline \multirow{2}{*}{ lymphosarcoma, and reticulosarcoma } & 1 & $255 \cdot 0$ & 0 & - & 0 & - & 0 & - & 1 & 123.5 & 1 & $344 \cdot 1$ \\
\hline & 0 & & 0 & - & 1 & $170 \cdot 5$ & 0 & - & 0 & & 0 & - \\
\hline Leukaemia and aleukaemia & 1 & $89 \cdot 8$ & 0 & - & 2 & $79 \cdot 9$ & 1 & $56 \cdot 4$ & 1 & $48 \cdot 1$ & 1 & $133 \cdot 2$ \\
\hline $\begin{array}{l}\text { Cancer of all other } \\
\text { lymphopoietic tissue }\end{array}$ & 2 & $196 \cdot 6$ & 2 & $196 \cdot 3$ & 1 & $41 \cdot 0$ & 2 & $118 \cdot 8$ & 3 & $146 \cdot 9$ & 0 & - \\
\hline Diabetes mellitus & 0 & - & 4 & 223.5 & 4 & $95 \cdot 0$ & 0 & - & 3 & $83 \cdot 7$ & 1 & $82 \cdot 8$ \\
\hline Cerebrovascular disease & 4 & $90 \cdot 8$ & 4 & $86 \cdot 6$ & 15 & $120 \cdot 8$ & 9 & $111 \cdot 1$ & 12 & $100 \cdot 5$ & 4 & $110 \cdot 1$ \\
\hline All heart disease & 35 & $99 \cdot 5$ & 30 & $96 \cdot 1$ & 76 & $85 \cdot 7$ & 72 & $110 \cdot 3$ & 86 & $96 \cdot 7$ & 24 & $76 \cdot 1$ \\
\hline $\begin{array}{l}\text { Ischaemic heart disease } \\
\text { Chronic endocardial disease; }\end{array}$ & $\begin{array}{r}26 \\
2\end{array}$ & $\begin{array}{r}94 \cdot 1 \\
217 \cdot 0\end{array}$ & $\begin{array}{r}23 \\
3\end{array}$ & $\begin{array}{r}96 \cdot 0 \\
335 \cdot 1\end{array}$ & $\begin{array}{r}63 \\
1\end{array}$ & $\begin{array}{l}89 \cdot 9 \\
39 \cdot 7\end{array}$ & $\begin{array}{r}57 \\
4\end{array}$ & $\begin{array}{l}109 \cdot 0 \\
248 \cdot 5\end{array}$ & $\begin{array}{r}71 \\
2\end{array}$ & $\begin{array}{l}98 \cdot 6 \\
82 \cdot 4\end{array}$ & $\begin{array}{r}19 \\
1\end{array}$ & $\begin{array}{r}74 \cdot 4 \\
129 \cdot 5\end{array}$ \\
\hline Other myocardial insufficiency & & & & & & & & & & & & \\
\hline Hypertension with heart disease & 3 & $434 \cdot 4$ & 1 & $141 \cdot 6$ & 1 & $55 \cdot 8$ & 2 & $156 \cdot 2$ & 5 & 292.9 & 0 & - \\
\hline All other heart disease & 3 & $56 \cdot 8$ & 3 & 61.6 & 11 & $87 \cdot 8$ & 8 & $90 \cdot 7$ & 8 & 70.9 & 4 & $95 \cdot 5$ \\
\hline Non-malignant respiratory disease & 7 & $121 \cdot 7$ & 7 & $132 \cdot 6$ & 15 & $96 \cdot 2$ & 11 & $106 \cdot 7$ & 18 & $116 \cdot 7$ & 5 & $102 \cdot 6$ \\
\hline Influenza and pneumonia & 0 & - & 1 & $59 \cdot 4$ & 6 & $128 \cdot 2$ & 4 & $126 \cdot 3$ & 4 & $85 \cdot 4$ & 2 & $133 \cdot 2$ \\
\hline Bronchitis, emphysema, asthma & 3 & $238 \cdot 0$ & 3 & $261 \cdot 7$ & 4 & $113 \cdot 5$ & 1 & $41 \cdot 7$ & 4 & $110 \cdot 6$ & 1 & 90.4 \\
\hline Other non-malignant respiratory disease & 4 & $147 \cdot 4$ & 3 & $122 \cdot 5$ & 5 & $67 \cdot 7$ & 6 & $126 \cdot 4$ & 10 & $140 \cdot 3$ & 2 & $88 \cdot 3$ \\
\hline Cirrhosis of liver & 3 & $82 \cdot 8$ & 1 & $28 \cdot 4$ & 9 & $118 \cdot 4$ & 4 & $64 \cdot 8$ & 5 & $79 \cdot 1$ & 2 & 73.0 \\
\hline All external causes of death & 25 & $121 \cdot 2$ & 20 & 119.4 & 22 & 68.9 & 25 & 96.9 & 18 & 85.0 & 3 & $31 \cdot 1 \star$ \\
\hline Accidents & 15 & $119 \cdot 3$ & 10 & $98 \cdot 1$ & 14 & $71 \cdot 8$ & 13 & $81 \cdot 7$ & 11 & $83 \cdot 4$ & 1 & $17 \cdot 0^{\star}$ \\
\hline Motor vehicle accidents & 9 & $128 \cdot 8$ & 5 & $89 \cdot 1$ & 8 & $77 \cdot 2$ & 8 & $95 \cdot 9$ & 7 & $108 \cdot 4$ & 1 & $34 \cdot 5$ \\
\hline Homicides and other external causes & 3 & 101.9 & 3 & $129 \cdot 6$ & 1 & $23 \cdot 7$ & 2 & $59 \cdot 6$ & 1 & $40 \cdot 5$ & 0 & - \\
\hline Unknown causes (in all & 2 & & 2 & & 3 & & 2 & & 3 & & 0 & \\
\hline
\end{tabular}

nknown causes (in al

${ }^{\star} \mathrm{p}<0.05 ;{ }^{\star \star} \mathrm{p}<0.01$. Category $1=$ open mould processing; category $2=$ mixing and closed mould processing; category $3=$ finish and assembly; category $4=$ $\star \mathrm{p}<0.05 ; \star \mathrm{p}<0.01$. Category $1=$ open mould processing; category $2=$ mixing and closed mould processing
plant office and support; category $5=$ maintenance and preparation; category $6=$ supervisory and professional. 
Table 9 Analysis of selected causes of death based on the proportional hazards model, with age, sex, cumulative exposure and duration of exposure to styrene as independent variables

\begin{tabular}{|c|c|c|c|c|}
\hline $\begin{array}{l}\text { Cause of death } \\
\text { (n) }\end{array}$ & $\begin{array}{l}\text { Independent } \\
\text { variable }\end{array}$ & $\beta$ & $S D$ & p Value \\
\hline $\begin{array}{l}\text { Cancer of oesophagus } \\
(n=14)\end{array}$ & $\begin{array}{l}\text { Age } \\
\text { Sex } \\
\text { Cum exp } \\
\text { Duration exp }\end{array}$ & $\begin{array}{r}0.048240 \\
-1.595667 \\
-0.000026 \\
-0.006152\end{array}$ & $\begin{array}{l}0.02263 \\
1.03879 \\
0.00154 \\
0.04894\end{array}$ & $\begin{array}{l}0.0330 \\
0.1245 \\
0.9864 \\
0.9000\end{array}$ \\
\hline $\begin{array}{l}\text { Cancer of lung } \\
(\mathrm{n}=162)\end{array}$ & $\begin{array}{l}\text { Age } \\
\text { Sex } \\
\text { Cum exp } \\
\text { Duration exp }\end{array}$ & $\begin{array}{r}0.057582 \\
-0.780307 \\
-0.000415 \\
-0.046059\end{array}$ & $\begin{array}{l}0.00664 \\
0.22151 \\
0.00061 \\
0.01656\end{array}$ & $\begin{array}{l}0.0001 \\
0.0004 \\
0.4997 \\
0.0054\end{array}$ \\
\hline $\begin{array}{l}\text { Uterine and other female } \\
\text { genital cancers }\end{array}$ & $\begin{array}{l}\text { Age } \\
\text { Sex }\end{array}$ & 0.013474 & 0.02121 & 0.5252 \\
\hline$(\mathrm{n}=24)$ & $\begin{array}{l}\text { Cum exp } \\
\text { Duration exp }\end{array}$ & $\begin{array}{r}-0.001506 \\
0.009251\end{array}$ & $\begin{array}{l}0.00215 \\
0.03655\end{array}$ & $\begin{array}{l}0.4839 \\
0.8002\end{array}$ \\
\hline $\begin{array}{l}\text { Cancer of kidney } \\
(n=15)\end{array}$ & $\begin{array}{l}\text { Age } \\
\text { Sex } \\
\text { Cum exp } \\
\text { Duration exp }\end{array}$ & $\begin{array}{r}0.052338 \\
-0.911843 \\
0.000686 \\
-0.013794\end{array}$ & $\begin{array}{l}0.02256 \\
0.76080 \\
0.00103 \\
0.04391\end{array}$ & $\begin{array}{l}0.0203 \\
0.2307 \\
0.5061 \\
0.7534\end{array}$ \\
\hline $\begin{array}{l}\text { Cancer of all lymphatic } \\
\text { haematopoietic tissues } \\
(\mathrm{n}=31)\end{array}$ & $\begin{array}{l}\text { Age } \\
\text { Sex } \\
\text { Cum exp } \\
\text { Duration exp }\end{array}$ & $\begin{array}{r}-0.025817 \\
-0.311723 \\
-0.001389 \\
0.025939\end{array}$ & $\begin{array}{l}0.01976 \\
0.45849 \\
0.00151 \\
0.03463\end{array}$ & $\begin{array}{l}0.1913 \\
0.4966 \\
0.3587 \\
0.4538\end{array}$ \\
\hline $\begin{array}{l}\text { Non-Hodgkin's lymphoma } \\
(\mathrm{n}=10)\end{array}$ & $\begin{array}{l}\text { Age } \\
\text { Sex } \\
\text { Cum exp } \\
\text { Duration exp }\end{array}$ & $\begin{array}{r}-0.007666 \\
0.134980 \\
-0.004145 \\
0.061336\end{array}$ & $\begin{array}{l}0.03459 \\
0.69719 \\
0.00449 \\
0.05176\end{array}$ & $\begin{array}{l}0.8246 \\
0 \cdot 8465 \\
0 \cdot 3562 \\
0.2360\end{array}$ \\
\hline $\begin{array}{l}\text { Multiple myeloma } \\
(\mathrm{n}=6)\end{array}$ & $\begin{array}{l}\text { Age } \\
\text { Sex } \\
\text { Cum exp } \\
\text { Duration exp }\end{array}$ & $\begin{array}{r}0.051887 \\
-0.667326 \\
0.000841 \\
-0.036599\end{array}$ & $\begin{array}{l}0.03628 \\
1.10126 \\
0.00159 \\
0.07579\end{array}$ & $\begin{array}{l}0.1526 \\
0.5445 \\
0.5959 \\
0.6292\end{array}$ \\
\hline $\begin{array}{l}\text { Leukaemia } \\
(\mathrm{n}=11)\end{array}$ & $\begin{array}{l}\text { Age } \\
\text { Sex } \\
\text { Cum exp } \\
\text { Duration exp }\end{array}$ & $\begin{array}{r}-0 \cdot 107919 \\
-0 \cdot 138699 \\
-0.002195 \\
0.073623\end{array}$ & $\begin{array}{l}0.04421 \\
0.78740 \\
0.00310 \\
0.07358\end{array}$ & $\begin{array}{l}0.0146 \\
0.8602 \\
0.4793 \\
0.3170\end{array}$ \\
\hline
\end{tabular}

Cum exp = cumulative exposure to styrene in ppm-years; duration exp = duration of exposure to styrene in years; sex: $0=$ men, $1=$ women. analysed with the Cox proportional hazards model. The selected causes of death included oesophageal cancer, lung cancer, cancer of the female genital organs (cervix uteri and other female genital organs), kidney cancer, all lymphatic and haematopoietic cancer, nonHodgkin's lymphoma, multiple myeloma, and leukaemia. Independent variables included in the model consisted of age, sex, cumulative exposure, and duration of exposure to styrene.

Table 9 shows that only age was a significant risk factor in some of the diseases. In particular, cumulative exposure was not associated with an increased mortality from any of these diseases. For lung cancer, a slightly inverse relation was found between mortality risk and duration of exposure. A similar analysis was performed with duration of exposure, which was highly correlated with cumulative exposure, removed from the model. The results were essentially the same. We also conducted similar analyses based on a stepwise regression for the inclusion of independent variables. Again, the results were similar-that is, neither cumulative exposure nor duration of exposure to styrene was a significant independent variable. The results based on the stepwise regression analyses are not presented.

\section{Discussion}

In the updated study, mortality from several causes of death showed significant increasesnamely, all causes, all cancers, lung cancer, oesophageal cancer, cancer of the cervix uteri, cancer of the other female genital organs, hypertensive heart disease, certain non-malignant respiratory diseases, motor vehicle accidents, and homicides. Death certificates indicated that $7 \cdot 6 \%$ of the decedents were non-white. Little was known of the rest of the cohort and the entire cohort was assumed to be white in the SMR calculations. Some of the SMRs could have been overestimated due to this assumption. It was likely that race specific analysis, had it been possible, would have resulted in lower risk estimates for several causes of death. For example, SMRs for all causes, all heart diseases, and external causes would have been reduced, although the exact amount of reduction could not be calculated. Because the proportion of white and nonwhite workers varied across subgroups within the cohort, the impact of this assumption might affect one subgroup more than another.

More importantly, when mortality patterns were examined by various variables of styrene exposure, no association was detected. In fact, most of the increases in mortality occurred among short term workers. High mortality from various causes among short term workers in other industries has been reported previously. For example, Wong and Musselman ${ }^{13}$ reported significantly increased mortality from lung cancer among slag wool workers employed for less than five years but not among those employed for five years or longer. Gubéran and Usel ${ }^{14}$ reported significantly increased mortality for all causes, all cancers, lung cancer, violent deaths, and other accidents in a cohort of workers employed for less than one year in the perfumery industry in Geneva. Similarly, McDonald et $a l^{15}$ reported significantly increased mortality from all causes, all cancers, respiratory cancer, heart disease, and other non-malignant respiratory disease among workers at a friction products factory with less than one year of employment, but such increases were not found among long term employees. These three examples suggest that poor health or health-influencing habits and low socioeconomic class characteristic of short term workers might be responsible for the increased mortality.

Furthermore, previous studies have linked low socioeconomic class to higher incidence of several diseases, including total mortality, all cancers, oesophageal cancer, lung cancer, cancer of female genital organs, heart disease, hypertension, and unintentional injury. ${ }^{1617}$ Low socioeconomic class has also been associated with poor survival in certain diseases due to inadequate health care, resulting in an even higher mortality. Most of the causes of death found to be significantly raised among short term employees in the present updated study were indeed the ones that have been linked to low socioeconomic class. The finding of a deficit in female breast cancer, for which an increased risk has been associated with high socioeconomic class, further supports this interpretation. ${ }^{18}$ Therefore, some of the increases in mortality might be explained by 
characteristics, lifestyle, and the low socioeconomic class of short term workers.

The possibility that short term workers might have been assigned to jobs with heavier exposure and consequently experienced a higher mortality risk has also been considered. The analyses with the six process categories essentially provided an effective stratification of jobs by level of exposure, and no mortality pattern was found. Thus it was unlikely that analysis based on duration of employment was confounded by job category or level of exposure.

More specifically, we now compare our findings on site specific cancers with the results from previous studies of reinforced plastics workers. In our study, mortality from lung cancer was significantly raised (SMR = $140 \cdot 6)$. Workers with less than one year of employment had the highest risk of lung cancer $(S M R=182 \cdot 7)$, whereas there was no increased risk among workers with 10 or more years of employment (SMR $=95 \cdot 2)$ or among workers in the highest ( $\geqslant 100$ ppm-years) cumulative exposure group (SMR $=104 \cdot 2)$. Similarly, Okun et al ${ }^{19}$ reported an excess of mortality from respiratory cancer among workers with minimal exposure $(S M R=155)$ but not among workers with high exposure to styrene $(S M R=71)$ at two United States boat building facilities. To our knowledge, no other epidemiological study in the reinforced plastics industry has reported a significant increase of lung cancer. In our original investigation, ${ }^{4}$ a nested case-control study attributed excess mortality from lung cancer to cigarette smoking. Therefore, the most likely explanation for the excess found in the update is cigarette smoking.

In the current study, there was a marginally significant increase of oesophageal cancer for the total cohort $(\mathrm{SMR}=191 \cdot 7,95 \%$ CI 104.8-321.7). No relation between oesophageal cancer and exposure to styrene was detected, however, and no increase was reported among workers in the highest ( $\geqslant 100$ ppm-years) cumulative exposure group (SMR = 97.3). The analysis based on the Cox proportional hazards model did not identify cumulative exposure as a risk factor. Kogevinas et $a l^{20}$ reported no increase in oesophageal cancer for workers exposed to styrene overall (SMR $=101)$. A non-significant increase of oesophageal cancer among laminators (SMR $=182$ ) was noted. No further detailed analysis on oesophageal cancer was reported. Kolstad et $a l^{21}$ reported a relative risk ( $R R$ ) for incidence of oesophageal cancer of 0.97 among men and an RR of 0.86 among women. Coggon et $a^{22}$ reported four deaths due to oesophageal cancer in their study, compared with 6.22 expected (SMR = $64)$. None of the authors has suggested any association between oesophageal cancer and exposure to styrene.

The most important risk factors for oesophageal cancer are tobacco, alcohol, and diet. ${ }^{23} 24$ Previous epidemiological studies have not found that occupational exposures play any significant part in the aetiology of oesophageal cancer. ${ }^{23-25}$ Although some epidemiological studies suggested that exposure to asbestos might play a part, these studies are far from convincing. ${ }^{26}$ In our study, although significant increases of both oesophageal cancer and lung cancer were found for the cohort as a whole, there was no increase from either cancer among the group with the highest exposure. This finding, together with the result from the previous case-control study, suggests that tobacco might also play a part in the excess of oesophageal cancer.

Significant mortality excesses were found for cancer of the cervix uteri $(S M R=283 \cdot 5)$ and cancer of other female genital organs $(S M R=201 \cdot 6)$. For the broad category all uterine cancer the SMR was 197.3, marginally significant. For workers with less than one year of employment, the SMR for all uterine cancer was significantly increased $(468 \cdot 6)$. Among workers in the highest $(\geqslant 100 \mathrm{ppm}$ years) cumulative exposure category, the SMR for cancer of the cervix uteri was $115 \cdot 0$. The SMRs for cancer of other female genital organs were similar for the lowest ( $<10 \mathrm{ppm}$ years) cumulative exposure category (SMR = 267.9) and the highest category (SMR = $269 \cdot 0$ ). No upward trend was found between exposure to styrene and cancer of the female genital organs.

Coggon et $a^{22}$ reported an SMR of 107 for cancer of the cervix uteri. Kogevinas et $a l^{20}$ reported only one death due to cancer of the cervix uteri among laminators $(S M R=112)$ and no deaths among other exposed workers. Kolstad et $a l^{21}$ reported RRs of $1 \cdot 25$ for cancer of the cervix, 0.68 for cancer of the uterus, and 0.67 for cancer of the ovary. As no other studies have shown significant excesses in risk for cancer of the female genital organs, and because the current study did not show any exposure-response associations, the overall raised risk estimates found in this study are more likely to be related to the nature of the workforce rather than the workplace.

For kidney cancer, there was a borderline significant increase for the entire cohort. Although there was no upward trend by duration of employment or cumulative exposure, the SMRs were raised among workers with 10 or more years of employment $(S M R=245 \cdot 3$, ns) and among workers with $\geqslant 100$ ppm-years of cumulative exposure ( $\mathrm{SMR}=255 \cdot 3$, ns). The analysis based on the Cox proportional hazards model did not show any relation between styrene exposure and risk of kidney cancer. A review of the employment records of the deaths from kidney cancer did not show any unusual pattern with respect to department, job title, or plant location.

Coggon et $a l^{22}$ reported three observed deaths due to kidney cancer compared with 3.93 expected $(S M R=76)$. Kolstad et $a l^{21}$ reported $R R$ s of 0.97 and 0.73 for incidence of kidney cancer among male and female workers respectively. Kogevinas et al ${ }^{20}$ also reported a deficit of kidney cancer (SMR = 69). Thus kidney cancer has not previously been linked to exposure to styrene. On the other hand, increased risk of kidney cancer 
has been reported among cigarette smokers, although the magnitude of increase is lower than that for other tobacco related cancers. Other than the possibility of cigarette smoking, we are unable to offer an explanation for the increased risk of kidney cancer in our study.

For lymphatic and haematopoietic cancers, our findings of no increased risk are consistent with the results of the studies of reinforced plastics workers in the United States reported by Okun et $a l^{19}$ and in the United Kingdom reported by Coggon et al. ${ }^{22}$ Kolstad et $a l^{21}$ reported small non-significant increases for incidence of non-Hodgkin's lymphoma ( $R R=$ 1.27) and leukaemia ( $R R=1 \cdot 15)$ among men, but not among women $(R R=0.16$ for non-Hodgkin's lymphoma and $R R=0.80$ for leukaemia). On the other hand, there was a small deficit from multiple myeloma in men ( $R R=0.80)$ but a slight increase in women $(R R=1 \cdot 36)$. Kogevinas et $a l^{20}$ did not find increases in any specific haematologic malignancies for their total cohort. Combining non-Hodgkin's lymphoma, Hodgkin's disease, and leukaemia into a single disease category, Kogevinas et $a l^{20}$ reported an SMR of 197 (95\% CI 85-387) for workers with more than one year of exposure and 20 or more years since first exposure.

As such, the conclusions regarding lymphatic and haematopoietic cancers from these other studies are equivocal. Even though some authors are reluctant to rule out an association between exposure to styrene and an increased risk of cancer of the lymphatic and haematopoietic tissues, the data supporting such an association are weak at best.

In our study, we did not find any significantly increased mortality from cancer of the lymphatic and haematopoietic tissues, or from any of the more specific diagnostic categories, including non-Hodgkin's lymphoma, Hodgkin's disease, multiple myeloma, and leukaemia in the overall cohort. In fact, small non-significant deficits were found for several specific sites. When the data were analysed by duration of employment in specific process categories, duration of styrene exposure, and cumulative exposure, no relation with any specific haematological malignancies was detected. Furthermore, no pattern or trend was detected when the analysis was stratified by latency and cumulative exposure. Our updated study has adequate power $(a=0 \cdot 05$, $\beta=0 \cdot 20$ ) to detect RRs as small as 1.44 for all lymphatic and haematopoietic cancers, 1.82 for non-Hodgkin's lymphoma, 2.52 for multiple myeloma, and 1.74 for leukaemia.

It should be noted that the estimates of styrene exposure presented in this report may be conservative for several reasons. Firstly, in the $\mathrm{AD}$ Little study, historical estimates tended to be conservative. Secondly, exposure was truncated in 1977 . Only $27 \%$ of the cohort members who were active in 1977 could have been affected by this exposure truncation. Truncated exposure has been used in epidemiological analysis based on the rationale that exposures received shortly before diagnosis or death (up to 10 or 20 years for some cancers) have little or no impact on the disease process. Nevertheless, some of these $27 \%$ cohort members might have been misclassified in some of the analyses. Thirdly, for a few workers, no quantitative exposure estimates were available and their jobs were assigned to the lowest category. This lack of exposure estimates might have resulted in a misclassification of some workers. The potential misclassification would have affected only a few workers in some of the analyses, however, and would not have changed the major findings of the study.

Finally, some limitations of the original study have been substantially improved in the present update. The study has been extended for a further 12 years of observation. The number of deaths have increased from 499 to 1628. The statistical power based on the updated data is adequate in detecting a modest increase in risk for most diseases. The quality of the vital status data has also been improved substantially. The percentage of workers lost to follow up has been reduced from $16 \cdot 1 \%$ to $3.5 \%$, and the percentage of outstanding death certificates from $9 \cdot 4 \%$ to $2 \cdot 6 \%$. Equally important are the improvements in exposure assessment in the current updated study. A quantitative cumulative exposure index based on ppm-years was reconstructed for each cohort member. Exposure-response analyses based on such a quantitative exposure index have greatly enhanced our interpretation of the data. To our knowledge, our study is the only one with such quantitative analyses.

\section{Conclusion}

In the present update, mortality from some causes showed significant increases-namely, all causes, all cancers, oesophageal cancer, lung cancer, cancer of cervix uteri, cancer of the other female genital organs, hypertensive heart disease, certain non-malignant respiratory diseases, motor vehicle accidents, and homicides. No relation between exposure to styrene and these increases in mortality was found, however. In fact, most of the mortality excesses could be attributed to short term workers. The most likely explanations for these increases in mortality were low socioeconomic class, smoking, and lifestyle factors characteristic of short term workers.

There was no increased mortality from lymphatic and haematopoietic cancers overall or from any specific haematological malignancy. In particular, no increase in mortality from non-Hodgkin's lymphoma, Hodgkin's disease, multiple myeloma, or leukaemia was found. Furthermore, no exposure-response relation between exposure to styrene and any of these haematological malignancies was detected. We, therefore, found no evidence that workers in the reinforced plastics industry in this study experienced any increased risk of lymphatic and haematopoietic cancers as a result of their exposure to styrene. 
We express our appreciation to the Styrene Information and Research Center (SIRC) and its member companies for sponsoring this study. Additionally, the staff at each of the 30 plants participating in the study contributed valuable data to plath the original study and the update. We express our appreoth the original study and the updat. ciation the SIRC Epidemiology Committee for valuable uggestions and comments, and to the staff at ENSR (especially Rosanna Hollie and Melissa Hays) for technical an We also thank the staff at the National Death Index and state health departments for providing death certificate information.

1 Preston RJ. The potential mutagenicity of styrene and its metabolites. SIRC Review 1990;1:25-31.

2 Anwar WA, Shamy MY. Cytogenetic and biomedical changes in workers exposed to styrene. [abstract]. changes in workers exposed to styrene. [abstract]. International symposium on health hazards of

3 Scott D. Cytogenetic studies of workers exposed to styrene: A review. [abstract]. International symposium on health hazards of butadiene and styrene. Espoo, Finland, 18-21 April, 1993

4 Wong O. A cohort mortality study and a case-control study of workers potentially exposed to styrene in the reinforced plastics and composites industry. $\mathrm{Br} \mathrm{F}$ Ind Med 1991;47:753-62.

5 Kogevinas M, Boffetta P. Letter to the editor. $B r f$ Ind Med 1991;48:575.

6 Wong $\mathrm{O}$. Reply to Kogevinas and Boffetta. $\mathrm{Br} \mathcal{F}$ Ind Med ong O. Reply to

7 Marsh GM, Preininger M. OCMAP, a user oriented occupational cohort mortality analysis program. American Statistician 1980;34:245-6.

8 Cox DR. Regression models and life tables (with discussion). Fournal of the Royal Statistical Society 1972;34: $187-220$.

9 Breslow NE. Analysis of survival data under the proportional hazards model. International Statistical Review 1975;43:45-58.

10 SAS Institute Inc. SAS/STAT Software (version 6). Cary, North Carolina: SAS Institute, 1991.

$11 \mathrm{AD}$ Little Inc. Industrial hygiene evaluation of retrospective mortality study plants. Washington, DC: Technical tive mortality study plants. Washington, DC: Technics

12 Pickle LW, Mason TJ, Howard N, Hoover R, Fraumeni JF. Atlas of US cancer mortality among whites: 1950-1980. Research Triangle Park: US Department of Health and
Human Services, National Institutes of Health, DHHS pub No (NIH) 87-2900, 1987.

13 Wong O, Musselman RP. Carcinogenicity of insulation wools: further comments and some new data. Regul Toxicol Pharmacol 1993;18:202-5.

14 Gubéran E, Usel M. Unusual mortality pattern among short term workers in the perfumery industry in Geneva. short term workers in the perfum

15 McDonald AD, Fry JS, Woolley AJ, McDonald JC. Dust exposure and mortality in an American chrysotile asbestos friction products plant. $\mathrm{Br} \mathcal{F}$ Ind $\mathrm{Med} 1984 ; 41$ : 151-7.

16 Baquet CR, Horm JW, Gibbs T, Greenwald P. Socioeconomic factors and cancer incidence among Blacks and Whites. 7 Natl Cancer Inst 1991;83:551-7.

17 Kaplan GA, Haan MN, Syme SL, Minkler M, Winkleby M. Socioeconomic status and health. In: Amler RW, Dull $\mathrm{HB}$, eds. Closing the gap: the burden of unnecessary ill ness. New York: Oxford University Press, 1987.

18 Petrakis NL, Ernster VL, King MC. Breast. In Schottenfeld D, Fraumeni JF, eds. Cancer epidemiology' and prevention. Philadelphia: WB Saunders Co, 1982.

19 Okun AH, Beaumont JJ, Meinhardt TJ, Crandall MS. Mortality patterns among styrene-exposed boatbuilders Am F Ind Med 1985;8:193-205.

20 Kogevinas M, Ferro G, Saracci R, et al. Cancer mortality in an international cohort of workers exposed to styrene. In: Sorsa M, Peitonen K, Vainino H, Hemminki K, eds. Health hazards of butadiene and styrene. Lyon: International Agency for Research on Cancer sci publ No $127,1993$.

21 Kolstad HA, Lynge E, Olsen J. Cancer incidence in the Danish reinforced plastics industry. In Sorsa $M$, Peitonen K, Vainino H, Hemminki K, eds. Health Hazards of butadiene and styrene. Lyon: International Hazards of butadiene and styrene. Lyon: International
Agency for Research on Cancer sci publ No 127, 1993.

22 Cogon D, Osmond C, Pannett B, Simmonds S, Winter PD, Acheson ED. Mortality of workers exposed to PD, Acheson ED. Mortality of workers exposed to styrene in the manufacture of glass-reinforced

23 Day NE, Muñoz N. Esophagus. In: Schottenfeld D and Fraumeni JF, eds. Cancer epidemiology and prevention. Philadelphia: WB Saunders Co, 1982

24 Yu MC, Garabrant DH, Peters JM, Mack TM. Tobacco, alcohol, diet, occupation, and carcinoma of the esophagus. Cancer Res 1988;48:3843-8.

25 Magnani C, Coggon D, Osmond C, Acheson ED. Occupation and five cancers: a case-control study using death certificates. Br f Ind Med 1987;44:769-76.

26 Doll R and Peto J. Other asbestos-related neoplasms. In: Antman K, Aisner J, eds. Asbestos-related malignancy. Orlando: Grune and Stratton Inc, 1986.

\section{Destruction of manuscripts}

From 1 July 1985 articles submitted for publication will not be returned. Authors whose papers are rejected will be advised of the decision and the manuscripts will be kept under security for three months to deal with any inquiries and then destroyed. 